\title{
IN DEFENSE OF THE FREEDOM OF THE PRESS: THE INDONESIAN PLAYBOY MAGAZINE CASE STUDY
}

\author{
M. Sofyan Pulungan ${ }^{1}$
}

\begin{abstract}
One of the most observable achievements in the development of liberal democracy in Indonesia after the fall of the Soeharto's New Order is the flourishing freedom of the press. One notable case was the Indonesian Playboy magazine and court decisions pertaining to it, which was successful in drawing massive public and even international attention. By thoroughly describing thoughts, feelings, values, and beliefs of various actors involved, this article explains the impacts of liberal democracy experimentation in Indonesia after the amendment of 1945 Constitution. This case has provided an excellent opportunity in observing the rule of law in enforcing the freedom of the press in Indonesia facing social cultural elements strongly adhered to by Indonesian people.
\end{abstract}

Keywords: Freedom of the Press, Indonesian Law, Playboy Magazine

\begin{abstract}
Abstrak
Salah satu pencapaian yang terlihat dalam perkembangan demokrasi liberal di Indonesia pasca runtuhnya Orde Baru Soeharto adalah berkembangnya kebebasan pers. Kasus yang kemudian cukup krusial adalah majalah Playboy Indonesia dan putusan pengadilan yang berkaitan dengannya, yang mana berhasil menarik perhatian publik yang masif dan bahkan perhatian dunia internasional. Dengan benar-benar mendeskripsikan pemikiran, perasaan, nilai, dan kepercayaan dari berbagai pelaku yang terlibat, artikel ini menjelaskan dampak-dampak dari percobaan demokrasi liberal di Indonesia pasca amandemen UUD 1945. Kasus ini telah membuka kesempatan yang sangat baik dalam mengamati rule of law dalam melaksanakan kebebasan pers di Indonesia menghadapi elemen sosial budaya yang sangat ditaati oleh masyarakat Indonesia.
\end{abstract}

Kata Kunci: Kebebasan Pers, Hukum Indonesia, Majalah Playboy

\section{Introduction}

The fall of Soeharto's New Order ${ }^{2}$ in 1998 signaled the advent of a new period in Indonesian legal and political history, commonly referred as the "reformation era." 3 This period was signified by, amongst others with amendment of the 1945 constitution, the first ever in the history of Indonesia.

1 Lecturer, Faculty of Law, Universitas Indonesia. This article is a part of author's thesis defense as amended in the International Institute for Sociology of Law, Spain, under the supervision of Dr. Angela Melville. The author can be reached at sofyan.pulungan@gmail.com.

${ }^{2}$ Lindsey, Timothy. (1999). Introduction to an Overview of Indonesian Law in Indonesia Law and Society. Timothy Lindsey ed., the Federal Press Sydney. p. 1-2. The New Order refers to the administration under the leadership of Soeharto from March, 1966 to May 21, 1998 where he resigned and succeeded by Vice President BJ Habibie.

${ }^{3}$ Arinanto, Satya. (2003). Hak Asasi dalam Transisi Politik di Indonesia (Human Rights on Political Transition in Indonesia). Pusat Studi Hukum Tata Negara Fakultas Hukum Universitas Indonesia, Jakarta. p. 247-57 
During this period, the amendments of the constitution was said to indicate the advent of liberal democracy, the rule of law and the protection of human rights in Indonesia. ${ }^{4}$

The first measure taken by the new administration was the restoration of civil and fundamental freedoms. This is signified by a more spacious room for rights to fundamental freedoms i.e. 1) freedom of expression and freedom of the press, 2) freedom of gathering, and, 3) freedom of association..$^{5}$ Moreover, the government and the House of Representatives also adopted a human rights law (Law No. 39 of 1999 on Human Rights) ${ }^{6}$ and a law concerning the formation of a Human Rights Court (Law No. 26 of 2000 on the Human Rights Court $)^{7}$, substantially derived from human rights international instruments. ${ }^{8}$

The restoration of civil and fundamental freedoms after the New Order regime brought about significant effects to democratic development in Indonesia, especially on the freedom of the press. During the New Order, government control of the press was effectively performed by two kinds of methods. Firstly, the requirement to acquire government licenses for press and publishing businesses. With this license, news agencies could be shut down should it contradict with government policies. Secondly, criminalization of the press ${ }^{9}$ by means of the invalidated Press Law (Law No. 11 of 1966 on the Press) ${ }^{10}$ and the Penal Code. ${ }^{11}$ Journalists whose works were considered a violation of the law and the code were often imprisoned. With the control of licensing and the criminalization of press, the freedom of the press was successfully restrained.

After the fall of the New Order, a new Press Law ${ }^{12}$ was adopted, bringing in a new page in guaranteeing the freedom of the press in Indonesia. This law abolished mandatory government licenses for the press and publishing businesses, as well as any other form of government intervention to the press such as press criminalization and other regulations prohibiting the freedom of the press. As a result, free press mushroomed and became one of the important actors in the development of democracy in Indonesia. Not

${ }^{4}$ Lindsey, Timothy. (2004). Indonesia: Devaluing Asian values, Rewriting rule of law in Asian Discourses of rule of law, Theories and Implementation of rule of law in Twelve Asian Countries, France and the US. Routledge, London and New York. p. 296

5 Nusantara, Abdul Hakim G. (2006). Arah Kebijakan Pembangunan Hukum Di Bidang Perlindungan, Pemajuan dan Penegakan Hak Asasi Manusia in Seminar Arah Pembangunan Hukum Menurut UUD 1945 Hasil Amandemen (Direction of Law Development On Field of Protection, Advancement and Enforcement of Human Rights in Seminar entitled "Direction of Law Development according to the Amandments of Indonesian Constitution 1945"). BPHN Ministry of Law and Human Rights, Jakarta. p. 2

${ }^{6}$ Indonesia. Law regarding Human Rights. Law number 39 year 1999. SG. 1999-165.

7 Indonesia. Law regarding Human Rights Court. Law number 26 year 1999. SG. 2000-208.

${ }^{8}$ See Nusantara, above n 5, p. 1-2. The new administration and the House of Representatives also ratified various international instruments among others, the UN Covenant on Anti-Torture, Inhuman Punishment, and Other Cruel Behaviors, the UN Covenant on Anti-Racial Discrimination, a range of ILO Covenants and ultimately in 2005 the International Covenant on Civil and Political Rights and International Covenant on Economic, Social, and Cultural Rights.

${ }^{9}$ Batubara, Leo. (2006). Tujuh Tahun Pers Merdeka (Seven Years of Freedom of The Press), Kompas. p. 2

${ }^{10}$ Indonesia. Law regarding Pricipal Provisions of Press. Law number 11 year 1966. SG. 1966-40.

11 Indonesia. Law regarding Criminal Law Regulations (KUHP). Law number 1 year 1946. SG. 1958-127.

12 Indonesia. Law regarding Press. Law number 40 year 1999. SG. 1999-166. 
only did the press make critical inputs into government policies, it has also revealed numerous corruption scandals and engaged in apparent measures to combat discrimination and promote human rights protection for minorities and vulnerable groups.

Aside from playing positive roles as indicated above, this political liberalization era also begat new features to the Indonesian press, i.e. the emergence of new genres in entertainment newspapers, magazines, and tabloids heavily alleged with pornographic content. The presence of the "pornographic press" invited protests from various communities that felt offended with the content. The protests were conveyed peacefully by the people while complying with the democratic mechanism and prevailing legal system. The House of Representatives (Dewan Perwakilan Rakyat/DPR) responded to these protests by promising to prepare a Pornography Bill. ${ }^{13}$

Problems with the so-called pornographic press intensified when the Playboy magazine was scheduled for release. A very strong and widespread protest occurred not only in Jakarta, but also in other major cities in Indonesia. ${ }^{14}$ Hundreds of thousands of people attend mass rallies to oppose the introduction of the Indonesian edition of the magazine, with fundamentalist Muslim groups manning the utmost front lines of the rallies.

\section{Case of the Indonesian Edition of Playboy Magazine}

The Indonesian Edition of Playboy magazine (hereinafter Playboy magazine) began when a group of young professionals joined together under PT. Velvet Silver Media (VSM Company) acquired a license from Playboy Enterprises, Inc. ${ }^{15}$ to publish the Playboy magazine in Indonesia. The maiden edition of the magazine was released on 7th April 2006. However, the controversy has already swollen long before its scheduled release, due to VSM Company's revelation to public concerning the forthcoming release of Playboy magazine. ${ }^{16}$ Various religious groups, cultural circles, and civil society organizations opposed this publication. They argued that although the country has enjoyed the freedom of press and the freedom of expression, this freedom itself should respect norms, values, etiquette, and religious beliefs in the country.

An especially strong voice opposing the plan to publish the Playboy magazine came from Majelis Ulama Indonesia ${ }^{17}$ (MUI - Indonesian Council of

13 Indonesia. Law regarding Pornography. Law number 44 year 2008. SG. 2008-181. The law was enacted on Oct 30, 2008, subsequently after the Playboy controversy.

${ }^{14}$ Suara Karya Online, Aksi Penolakan Makin Marak (The Rejection Movement Become More Massive), available at http://www.suarakarya-online.com/news.html?id=134126 (last visited Oct 15, 2013).

15 See The New York Times News, Playboy Indonesia: Modest Flesh Meets Muslim Faith, available at, http://www.nytimes.com/2006/07/24/world/asia/24bali.html?fta=y (last visited on Desember $10,2013)$. The magazine is published under license in 20 countries, mostly in Europe. Indonesia is the first Muslim country the magazine has published in since a Turkish edition folded in the mid-1990s.

16 BBC Indonesia Online, Playboy Indonesia Mulai Beredar, available at http://www.bbc.co.uk/ indonesian/news/story/2006/04/060407_playboysale.shtml (last visited on January 2, 2014).

17 Assyaukanie, Luthfi. Fatwa and Violence in Indonesia. (2009). Religion of Society Journal, Volume 11, available at http://moses.creighton.edu/JRS/2009/2009-3.html (last visited on March 29, 2009). Majelis Ulama Indonesia, abbreviated MUI is a national level organization consisting of Islamic clerics and 
Ulemas). Anticipating the plan to publish the Playboy magazine and public demand concerning central government's immediate action to stop the circulation of the magazine, the Minister of Communication and Informatics, Sofyan Djalil, declared that the government has no authority to forbid the Playboy magazine under the new Press Law, anyone including government official could be liable for up to two years imprisonment should it lessen, censor, and or limit news coverage ${ }^{18}$ and circulation.

The Playboy magazine was published and circulated to the public as promised. The management responded to public pressure by stating that there will be no obscenity in any edition of Playboy magazine. The management also promised to comply with legal regulations prevailing in Indonesia. ${ }^{19}$ The first edition of Playboy magazine, contrary to public anxiety beforehand, was issued without nude women models. The Playmate rubric for example, usually contains nude poses in its original versions; however the Indonesian edition did not contain any nude models. Aside from works of photography depicting à la mode sexy women, Playboy magazine also typically contains articles on lifestyles, economy, social politics, and cultural issues. The language and diction used in the magazine was not at all pornographic, instead applied a high standard of quality journalism. Nevertheless, this fact did not stop public protests particularly from Islamic religious circles. Front Pembela Islam ${ }^{20}$ (FPI-The Front of the Defenders of Islam), one of the hardliners, went as far as conducting sweeps to stores that sold Playboy magazines. They confiscated these magazines from the stores and later burned them.

Several liberal groups, some from pro-democratic NGOs, academics, and journalists condemned FPI's actions. They gave support to Playboy Indonesia. The chairman of Aliansi Jurnalis Independen (AJI) Indonesia) ${ }^{21}$ (AJI-Alliance of Independent Journalists - Indonesia), Heru Hendratmoko, stated that the very existence of Playboy magazine is just a consequence of the freedom of information and the freedom of the press guaranteed by the constitution: ${ }^{22}$

scholars in Indonesia. MUI members originate from various Indonesian Islamic organizations and interest groups. Although MUI often issues its judgments (fatwa) for a wide range of matters related to Islamic law and the affairs of the ummat in general. However, there is no obligation for the state to obey these judgments.

18 Sofyan: Pemerintah Tak Berwenang Tutup Playboy (Sofyan: The Government Has No Rights to Shut "Playboy" Down), available at http://www.tempo.co/read/news/2006/04/11/05576069/SofyanPemerintah-Tak-Berwenang-Tutup-Playboy (last visited Desember 20, 2013).

${ }^{19}$ Detik News, Pengelola Playboy Berjanji Tidak Akan Memuat Foto Telanjang (Playboy's Manager promising Will Not Contain Naked Pictures), available at http://www.detiknews.com/index.php/detik. read/tahun/2006/bulan/04/tgl/07/time/133514/idnews/572587/idkanal/10 (last visited November 10, 2013).

${ }^{20}$ See Assyaukanie, above n 17. The Front of the Defenders of Islam (Front Pembela Islam/FPI) is a hard-line Islamic group in Indonesia known for violent actions. Assyaukanie writes before the assault towards the representation office of Playboy, FPI already has a history of attacks: Ahmadiyah sect (2005), Office of Islamic Liberal Organization (2005) and a citizen Lia Aminuddin (2006).

${ }^{21}$ AJI-Indonesia, available at http://aji.or.id/read/sejarah.html (last visited on January 1, 2014). AJI is an Indonesian journalist organization fighting for the freedom of the press since the New Order regime. Many members of AJI have been imprisoned, subject to violence, or lost their jobs due to their opposition. AJI also is a member of International Federations Journalist (IFJ), Southeast Asian Press Alliance (SEAPA) and International Freedom of Expression Exchange (IFEX).

${ }^{22}$ Interview with Heru Hendratmoko, Chairman, Aliansi Jurnalis Independen Indonesia (Alliance of Independent Journalist Indonesia). 
"Every person shall have the right to communicate and to obtain information for the purpose of the development of his/her self and social environment, and shall have the right to seek, obtain, possess, store, process and convey information by employing all available types of channels."

According to AJI, in a democratic and heterogeneous country like Indonesia, each person and group has to accept the difference of opinions, upholds the freedom of the press, and must not impose his/her belief onto others; moreover, such imposing of beliefs which is done by means of terror, intimidation, threat of physical violence violates of criminal law. After this violent protest, the police chief in Jakarta said they would ask the publishers to move operations to some other city. "For the time being while awaiting the investigation (of the attack), we will ask that the publishing of the Playboy magazine not be done in Jakarta." ${ }^{23}$ Despite this huge public controversy, Playboy magazine quickly sold out, and copies changed hands at three times the cover price.

On June 30, 2006, the local Jakarta prosecutor announced that Playboy Indonesia Chief Editor Erwin Arnada had been formally listed as suspects and will be tried for indecency charges based on Penal Code article 282. Additionally, two Playboy models were also charged, but the case never followed through and was consequently dropped. The prosecution stated that Arnada had upset society and damaged Indonesia's moral values. On 7 December 2006 court sessions commenced, with FPI always in attendance, where they attempted to intimidate the judge's into severely sentencing the Chief Editor. Nonetheless, this public pressure did not sway the judges' decision.

On April 05, 2007, the Board of Judges of the South Jakarta District Court, chaired by Efran Basuning ruled to reject the prosecutions from the Public Prosecutor in their decisions. The judges decided that while the magazine is a journalistic product exploiting sex appeal, it cannot fall into pornography category as indicted by the Public Prosecutors.

After the South Jakarta District Court dismissed the charges, notwithstanding on a technical point, stating that charges should have been brought under the Law No. 40 of 1999 on Press and not under Penal Code (lex specialis derogat legi generali - special law repeals general laws), the Public Prosecutors appealed the District Court Decision in the High Court of Jakarta, which on 22 October 2007 confirmed the original verdict. ${ }^{24}$

On 18 February 2008, the Public Prosecutors appealed the High Court Decision to the Indonesian Supreme Court by the following reasons ${ }^{25}$ :

a. the Board of Judges of the High Court misapplied the law by not considering

${ }^{23}$ Taipei Times, Jakarta Police Chief Asks 'Playboy' To Leave Town, available at http://www.taipeitimes.com/News/world/archives/2006/04/14/2003302634 (last visited on December 20, 2013).

${ }^{24}$ Jakarta High Court Decision number 255/PID/2007/PT.DKI. on 22 October 2007

${ }^{25}$ See Indonesia Media Defense Litigation Network (IMDLN), Institute for Criminal Justice reform (ICJR), and Lembaga Studi dan Advokasi Masyarakat (ELSAM), Amicus Brief on Erwin Arnada Vs. Republic of Indonesia, 2011, p. 10-11, available at: http://advokasi.elsam.or.id/wp-content/uploads/2014/01/2011_ amicus_brief_Kasus-Erwin-Arnanda.pdf (last visited on 14 May 2014) 
whether a legal rule has been applied in an improper manner (Article 253 (1) (a) of the Criminal Procedure Law);

b. the Board of Judges of the High Court did not apply a provision on Article 27 (1) of the Law No.14 of 1970 as amended by Law No.35 of 1999 on the Basic Principles of Judicial Power, stating that Judges as legal and justice enforcers should explore, comply, and understand legal values prevailing in society, particularly where Indonesia hold aloft their customs and traditions;

c. the Board of Judges of the High Court did not consider provisions on Article 182 (4) on the Criminal Procedure Law, where the Judges shall hold final consultations to reach a decision based on the bill of indictment and all that has been proven in the examination at trial, including the expert witnesses' testimony of Dr. Rudy Satriyo Munkantardjo, S.H., M.H. (criminal law expert), Drs. Amirsyah Tambunan, M.AG. (MUI), and Drs. Maryanto, M.Hum. (language expert).

d. the Board of Judges of the High Court's adjudication procedures was not complied with the provision on the Criminal Procedure law (Article 253 (1) (b)).

On 29 July 2009, it came surprisingly that the Supreme Court had reviewed the decision of the High Court and decided that Erwin Arnada was legally proved guilty in doing crimes against decency as indicted by the Public Prosecutors (primair indictment) and would be sentenced to two years' imprisonment. The Board of Judges of the Supreme Court, chaired by Mansur Kertayasa, considered that the Criminal Code (Article 282) was the appropriate regulation because the Law No.40 of 1999 on Press did not cover offences concerning publicly-displayed or dissemination writing or pictures that violated morality or decency. ${ }^{26}$ The Supreme court decision was received by Arnada on 23 June 2010 and legally binding. ${ }^{27}$

A request for reconsideration appeal by Erwin Arnada had been filed and received by the South Jakarta District Court on 12 October 2010. This reconsideration appeal was examined and decided by the Supreme Court with a different panel of judges. In summary, the Panel of Judges concurred with the first and second stage decisions of the South Jakarta District Court and the High Court, that the charges should have been brought under the Law No.40 of 1999 on Press. Thus, Erwin Arnada was finally released from prison. ${ }^{28}$

\section{Theoretical Framework}

In achieving the rule of law through the process of constitutional amendment which establishes the foundation of human rights and fundamental freedoms before unattainable in Indonesia. Basic rights such freedom of speech and consequently the freedom of the press have since then

\footnotetext{
${ }^{26}$ Supreme Court Verdict number 13 PK/PID/2011, 25 May 2011, p. 31-32

${ }^{27}$ Ibid.

${ }^{28}$ Ibid., p. 47
} 
challenged the effectiveness of the rule of law in Indonesia. ${ }^{29}$ These challenges may pose as one of many indicators which lead to believe that Indonesia is now on the road towards liberal democracy.

John Rawls' theories address issues that are of critical significance to understanding the rule of law in liberal democracy, in its theoretical dimensions and also in term of its achievement in practice. His thinking spans the relationship between the state and individual. Critically, Rawls seeks to insulate both individuals and society from the potentially damaging effect of intractable, possibly irresolvable, disputes based on differences in personal value. While his methodology rests on political theory, it explicitly assigns state institutions-particularly the judiciary-central roles, and gives priority to the realization of human rights and liberties. ${ }^{30}$

Rawls starts to build his concept of justice by criticizing utilitarianism and institutionalism that he considered as the basis of former concepts of justice. ${ }^{31}$ His theory of justice is a liberal effort to advocate egalitarianism. According to Rawls, a theory of justice must take into account any freedom and equality between individuals within society. Rawls developed his theory of justice around a main idea of "justice as fairness". Justice as fairness for Rawls is the purpose of social contracts. In this theory he articulates a fundamental statement of equality which Rawls sees as a "baseline". ${ }^{32}$ For Rawls, any departure from this baseline requires the agreement among citizens that such a departure would be to the benefit of all, and particularly to the least advantaged.

The egalitarian spirit put forward by Rawls in his theory of justice is not a naïve plea of equality, because the theory is based on the principle of reciprocity. ${ }^{33}$ Rawls simply puts an emphasis on specific protection to fundamental freedoms, which for him are the standards of civil and political rights acknowledged in liberal democracy, such as right to vote, right to be voted for a public office, right to self-defense, freedom of expression, freedom of speech and the like. Thus, these freedoms are important, for they are the fundamental values of mankind, and for that reason also they are referred to as fundamental freedoms. ${ }^{34}$

According to Rawls, the most all-encompassing right to fundamental freedoms is consistent with an equal right to freedom for everyone. With this he meant that freedom must not be sacrificed for other values or purposes, it is equally owned by everyone. One's fundamental freedom cannot be separated from other's fundamental freedom, thus everyone's fundamental freedom is intertwined. Although the principle of freedoms is given a top priority over

${ }^{29}$ Lindsey, above n 4, p. 296

${ }^{30}$ Fenwick, Stewart. (2007). Reading Rawls in Asia: Political Liberalism and rule of law in Indonesia. Paper presented on the 4th Annual ASLI Conference, Jakarta, May 2007. p. 1

31 Rawls, John. (2001). A Theory of Justice. The Belknap Press, Cambridge. p. 27

32 Rawls, John. (2002). The Law of People with the Idea of Public Reason Revisited. Harvard University Press, Cambridge. p. 41

${ }^{33}$ Rawls, above n 31, p. 10

${ }^{34}$ Ahida, Ridha. Konsep Keadilan pada Masyarakat Multikultural Dilihat dari Perspektif John Rawls dan Will Kymlicka (Justice conception on Multicultural Society Seen from John Rawls and Will Kymlicka's Perspective). (2005). (unpublished Ph.D. dissertation, Universitas Indonesia) (on file with author), p. 125126 
other values and cannot be surrendered, it is however, according to Rawls, not absolute. Since one's fundamental freedom in practice constantly confronts other fundamental freedoms equally owned by others, when a conflict occurs between these fundamental freedoms, a compromise therefore must be made available to fundamental freedoms with the widest and greatest scope. ${ }^{35}$

Another important idea of John Rawls is his notion of public reason. Rawls noted several facts that serve as its point of departure i.e.: (1) the fact of pluralistic views among the society be it from religious views, secular moralities, and so on; (2) the fact that such plurality is ever exist or permanently exist within the society; (3) the fact that such ever existing plurality can only be stifled by an oppressive rule of the state. Rawls uses a specific terminology to refer to the aforementioned views, i.e. comprehensive doctrines. ${ }^{36}$ According to Rawls, comprehensive doctrines originated from the "background culture" of democracy. ${ }^{37}$ They are represented in the various religious, moral, or philosophical doctrines among which citizens cannot reach agreement, or find mutual understanding, because they give rise to irreconcilable differences of opinion. ${ }^{38}$ That is why they need to consider what kind of reasons they must propose should there be fundamental political questions at stake. Rawls suggests that in public reason, the ideas of truth originated from comprehensive doctrines are replaced by politically reasonable ones, conveyed to the citizens.

For Rawls, comprehensive doctrines need to be replaced with an overlapping consensus; one of its main forms is what is known as political conception of justice. Comprehensive doctrines pretend to embrace all aspects of live, including general moral wisdom, as well as public and private life; whereas political conception has a narrower scope, for instance, it is limited only to political policies, right to vote, and so forth. In public reason, religious belief is not abandoned nor discarded. It is right of every citizen to adhere to any faith or belief. "Every comprehensive doctrine, both religious and secular, may be proposed in political arguments at any time, but it must always be borne in mind that other has exactly the same right to do so, and the argument should be one that may, but not always must, be agreed by other members of society." ${ }^{39}$

Central to the idea of public reason is that it neither criticizes nor attacks any comprehensive doctrine, religious or nonreligious, except insofar as that doctrine are incompatible with essentials of public reason and a democratic polity. The basic requirement is that a reasonable doctrine accepts a constitutional democratic regime and its companion idea of legitimate law. ${ }^{40}$ What is important here is how to convey an understandable and appraisable argument notwithstanding what comprehensive doctrine one adheres.

This article utilizes some the above concepts of John Rawls to analyze the development of the rule of law in a liberal democracy in Indonesia

${ }^{35}$ Rawls, above n 31, p. 54, 179, 474.

${ }^{36}$ Bagir, Zainal Abidin. Agama dalam Nalar Publik (Religion in Public Perspective). (2006). Paper on an Introduction to Discussion in Nurcholish Madjid Memorial Lecture, Yogyakarta, September 18, 2006. p.3

\footnotetext{
37 Rawls, above n 32, p 134

38 Ibid., p. 131-4

${ }^{39}$ Bagir, above n 36, p. 3

${ }^{40}$ Rawls, above n 32, p. 132
} 
after the fall of the New Order regime. The element of rule of law in liberal democracy in Indonesia to be examined in this article is, the implementation of freedom of expression and freedom of the press, which can be included amongst civil and fundamental freedoms. Within this analysis, it is important to take into account the fact that pluralism in values and social norms is an irreducible fact of Indonesian life. ${ }^{41}$ The 'fact of pluralism' here refers to the coexistence within nations of divergent value systems reflecting different cultural, religious, philosophical and moral conviction. This social pluralism is reflected in a plural legal system that encompasses traditional and Islamic elements, in addition to its liberal democratic core. ${ }^{42}$

The implementation of the freedoms is viewed not only from constitutional and legal perspectives, but most importantly also from other social perspectives that considerably influence it i.e. systems of religion, culture, and politics. With adequate understandings of the mechanism of these other social system outside the legal system, in particular the relation between Islam, the state, and Indonesian Muslims' perception concerning liberal democracy, any social factors contributed to the controversy of Playboy magazine Indonesian edition can be critically examined. It is anticipated that this article will provide decisive answers to skeptical questions posed by western scholars on the implementation of democracy in Muslim countries in general, and Indonesia in particular.

\section{IV.Case Study Findings}

The Playboy magazine case has highlighted some very important socio-legal debates and tensions within Indonesian society. In the socio-legal context, this article refers to the existing religious, cultural, and political system in Indonesia which strongly influences the values, views of life, and customs of the Indonesian people; this in turn interacts with the national legal system developed by the state.

\section{Freedom of the Press in Theory vs. Freedom of the Press in Action}

The fall of the New Order has indeed brought significant changes to the comprehensive adoption of universal human rights not only in national legislation and ratification of international instruments, and also within the constitution. The question remains, however, on how Indonesia will implement and enforce those legal stipulations on human rights? The Playboy magazine case of provides a stark answer to the question, as apparent in Chief Editor of Playboy Indonesia Erwin Arnada's defense before the court when he described his feelings of being unjustly discriminated.

"This is clearly discrimination. There are many other magazines with blatant visual depiction of vulgar and tasteless pornography. They go on without fussing. Why must Playboy accept all the blame?"43

\footnotetext{
${ }^{41}$ Bowen, John R. (2003). Islam, Law and Equality in Indonesia: An Anthropology of Public Reasoning. Cambridge University Press, Cambridge. p. 257

${ }^{42}$ Fenwick, above at 30, p. 2

43 Antara Online, Pemred Playboy Tolak Pengenaan Pasal KUHP (Playboy's Editor in Chief Rejects The Accusation from KUHP Verse), available at http://www.antaranews.com/berita/56746/pemred-play-
} 
Hardliner opposition followed by legal proceedings forced Erwin and his colleagues to, despite legal and constitutional guarantee of protection to the freedom of expression and the freedom of the press, voluntarily shut down their business in Jakarta.

Various voices from secular and moderate Muslims circles condemned violent actions conducted by FPI toward Playboy magazine office because it represented a threat to democracy. However, they generally cannot deny the "closed" nature of Indonesian culture toward sexuality, and that many parts of the Indonesian community saw Playboy as a worldwide icon for pornography. One respondent argued that Playboy's reputation is just too much for most Indonesians, bearing in mind that most of them still to some extent show an over reaction towards sexual liberty. ${ }^{44}$ The real encumbrance to human rights implementation with regard to Playboy Indonesia case is, therefore, the culture of Indonesian people itself. A similar opinion is also expressed by a liberal respondent:

"Our culture still cannot stand the scene of so many Indonesians welcoming Playboy magazine just so with open arms. This requires a long process, because it has to do with cultural sense."45

Aside from this notion of culture in a broader sense, perception of religion as a social system in Indonesia clearly contributes to painstaking implementations of the freedom of the press in this case. For fundamentalist Muslim groups such as FPI and HTI for instance, there must be no aspects of living that are separate from the Syari'ah, as the Syari'ah was are sent to encompass all aspects of life. In other words, everything must be in accordance with the Syari'ah, and that it leaves no place to share with other set of norms or values.

"We FPI are of a steadfast position that our sole standard is the Syari'ah. What is prohibited by Syari'ah, we prohibit; what is allowed by Syari'ah, we allow. We do not care if it is the freedom of the press or whatever, ahlan wa sahlan, as long as Syari'ah allows, we allow; but if Syari'ah prohibits, we will prohibit, at all cost." ${ }^{\prime 46}$

Moderate Muslims has taken very cautious steps in dealing with Playboy magazine case. Prior to its publication, the two largest Islamic Organizations in Indonesia, Nahdatul Ulama (NU) and Muhammadiyah are among those who strongly oppose the plan to publish an Indonesian version of Playboy magazine, but when the magazine was indeed published and triggered violent actions from the hardliners, they too condemn such actions. "I cannot tolerate violence, sweeping, anarchism on behalf of anything," ${ }^{\prime 4}$ stated Din Syamsuddin, the Chairman of Muhammadiyah.

boy-tolak-pengenaan-pasal-kuhp (last visited on November 29, 2013).

${ }^{44}$ Interview with, Franz Magnis Suseno, Priest, Roman Catholic Church.

45 Interview with Atmakusumah Astraadmadja, expert on journalist ethics and Ex-Chairman of the Press Council.

${ }^{46}$ Interview with Habib Rizieq Zieghab, Head, Islamic Defenders Front (FPI).

47 Detik Online, Muhammdiyah Kecam Pengrusakan Kantor Playboy [Muhammadiyah Protests Vandalism of Playboy Office], available at: http://news.detik.com/read/2006/04/14/103726/575673/1 $0 /$ muhammadiyah-kecam-pengrusakan-kantor-playboy (last visited on September 1, 2013). 
Islamic moderate groups were in a difficult position in this case. Democracy in Indonesia can come about only with popular support, but in the Playboy case they faced opposition from the grass root level, including those who predominantly live in rural areas, who find it hard to accept the logic that Playboy's presence is but a consequence to the implementation of the freedom of expression. As one liberal Islamic activist argued:

"It is nearly impossible for NU and Muhammadiyah to support the publication of Playboy magazine because they must deal with the mass in the grass root level, particularly in rural areas, which used to think that Playboy is identical with pornography. Once NU and Muhammadiyah shows a hint of support to Playboy, they will instantly be of an opinion that NU and Muhammadiyah support pornography." 48

A similar opinion was also put forward by a Catholic priest:

"Although violence toward Playboy is by no means unjustifiable, for me Playboy must not necessarily be published in this country. It is not necessary for Indonesia to imitate the freedom related to sexuality as practiced in western countries." 49

Furthermore, this respondent explained that there is a wide gap in customs and perspectives between Indonesian culture and Western culture with regard to sexuality; a gap that must be wisely and thoughtfully bridged, and certainly not with the publication of Playboy magazine.

Despite all the controversies around it, the Playboy magazine case is an excellent lesson about how difficult it will be to uphold a legally and constitutionally guaranteed freedom of expression and freedom of the press in the midst of traditional culture which still strongly holds public expressions of sexuality to be a taboo. Some however, believe that the publication of Playboy magazine is important in the sense of a cultural breakthrough, as one respondent explained:

"If seen from a cultural perspective, the incident of Playboy Indonesia is most important. It is a cultural breakthrough that force its way against a cultural stronghold, that such thing will never happen in Indonesia-something that the Publishers must have well aware about. But they did it, they break through it." ${ }^{\prime \prime}$

This respondent further encourages everybody to find courage to initiate other creative breakthroughs which leads to cultural advancement.

\section{The Rule of Law vs. Weakness of Legal Institution}

Post-Soeharto Constitutional amendment and legal reform has asserted Indonesian's new commitment to the rule of law. The Playboy magazine case provides a good portrayal of how the rule of law is implemented amidst a strong influence of religious groups' interventions. These interventions have begun even before the Playboy magazine case was heard before a court of law,

\footnotetext{
${ }^{48}$ Interview with Abdul Qodir Agil, Islamic liberal activist.

49 Rizieq, above $\mathrm{n} 46$.

50 Atmakusumah, above n 45 .
} 
where MUI DKI Jakarta paid a visit and urged the Jakarta Regional Police Chief to take legal measures toward the Playboy magazine management because they have committed crime against decency.

Subsequently, MUI also urged the police to confiscate all Playboy magazines already circulating whilst taking legal measures against those who sell or circulate the magazines in Jakarta. According to MUI, Playboy magazine is a pornographic magazine, and therefore in violation to the values of decency, religious as well as state law i.e. Penal Code. ${ }^{51}$ Anticipating the request and violent actions conducted by Islamic hardliners toward Playboy magazine's office, the city police advised Playboy Indonesia to give up on the Jakarta market. ${ }^{52}$

The police measures in asking Playboy to leave Jakarta concerned many liberal observers. One interviewee argued that the measures clearly indicate that Indonesia is indeed not yet a democracy and the rule of law is still far from being achieved:

"If we want to be consistent to the rule of law, Playboy must never be sent away from Jakarta. The police have nothing to justify their measures; they are even in breach to the article that prohibits censoring, shutting down, and cancellation of broadcasting." 53

This respondent further argued that, "If we want to be acknowledged as a democracy, a state based on the law, state apparatus, in this case the police must support the freedom of the press, the freedom of expression, and not do otherwise." 54

Another respondent opined that Playboy case must be handled by legal institutions i.e. the court. As long as the magazine is not in violation to any prevailing laws e.g. Press Law and the Penal Code, its publication and circulated could not be prohibited.

"the majority of Indonesian people has accepted and practiced democracy, which is why we have to guard and protect our democracy according to the constitution and Pancasila. ${ }^{55}$ Pancasila that advocates the idea of secularization in a positive sense has asserted that the state shall not take side with any specific religion, including the religion of the majority. ${ }^{56}$

51 Republika Online, Sikap MUI DKI Jakarta Terhadap Playboy (MUI DKI Jakarta's Stand to Playboy), available at http://www.republika.co.id/koran_detail.asp?id=244568\&kat_id=217 (last visited on September 15, 2013).

52 The Jakarta Post Online, MUI Jakarta Gets Behind Police On 'Playboy' Ban, available at http:// www.thejakartapost.com/headlines.asp (last visited on January, 2014).

${ }^{53}$ Atmakusumah, above $\mathrm{n} 45$

54 Ibid.

55 See Onghokham \& Andi Achdian, Pancasila: Dari Kontrak Sosial Menjadi Ideologi Negara, Prosiding Simposium Peringatan Hari Lahir Pancasila, Restorasi Pancasila: Mendamaikan Politik Identitas dan Modernitas (Pancasila: From Social Contract to State Ideology, Prosiding Symposium of Commemoration of Pancasila's Birth, Pancasila Restoration: Reconcile Identity and Modenity's Politic). (2006). Depok, Brighten Institute. p. 99. Pancasila is the philosophical basis of the Republic of Indonesia, but it can also be perceived as a kind of social contract and a national compromise among the founding fathers. The birth of Pancasila is an Indonesian nation-wide compromise in its wholeness, notwithstanding differences in ideology, belief, religion, or other departmental interests whatsoever.

${ }^{56}$ Suseno, above $\mathrm{n} 44$. 
This respondent further concludes, "Democracy must not violate human rights, this is very essential. Human rights are the main elements of the rule of law whilst at the same time also serve as a control to prevent majority dictatorship." ${ }^{57}$

Based on police investigation to the management of Playboy magazine and two models that have posed for the magazine, the police and prosecutor brought the case before the court while charging Erwin Arnada, the Chief Editor as in violation to the article on decency in the Penal Code article 282;58 the sessions started on 7 December 2006. Through four months of hearing sessions, on 5 April 2007 the judges declared that prosecutors' charge against defendant Erwin Arnada is not acceptable due to imprudence as they did not include the Law No. 40/1999 on the Press in their charge. ${ }^{59}$

Efran Basyuning, the Chairman of the Board of Judges for this case, said pictures of scantily dressed women could not, under criminal laws, "be categorised as pornography." ${ }^{60} \mathrm{He}$ was in opinion that according to the facts that were revealed in hearings it was apparent that Playboy magazine is a product of press; and therefore the Law of the Press must be prioritized in this case. Efran's argument is based on a legal maxim "lex specialis derogat legi generalis", which means a specific law shall put aside a general one. The implementation of this maxim, according to Efran, can be seen in the consideration of the Law of the Press. Furthermore, "the freedom of expression as stipulated in Article 28 of UUD 1945 must be protected," argues Efran. ${ }^{61}$ This decision is a final judgment of all stages legal proceedings for this case. that;

The Playboy magazine management gladly accepted the decision, saying

"This decision is a present for Playboy Indonesia, because on a day like this a year ago our magazine was premiered, which means that while working we've been through all these pressures for a year. This decision also shows that there is still appreciation to and sound awareness of the freedom of the press in this country." 62

57 Ibid.

58 KUHP, above n 11, art 282 concerning decency is often used to apprehend pornographers in Indonesia. However, since the enactment of the new Press Law in 1999, all crimes related to journalistic related photograph and or news coverage in mass media conducted by journalists were subject to the law according to the Lex Spesialis maxim. One virtue of this law is the decriminalization of journalism which switches imprisonment to fining against journalistic wrongdoers. In practice, however, it is not unusual that state apparatus still uses the Penal Code instead of the Press Law to deal with violations related to journalistic pictures or news coverage in mass media.

59 South Jakarta District Decision number 2362/Pid.B/2006/PN.Jak.Sel. on 05 April 2007

${ }^{60}$ Aljazeera Online, Playboy Indonesia 'not pornography', available at http://www.aljazeera.com/ news/asia-pacific/2007/04/200852511583340287.html (last visited on January 2, 2014).

61 Hukumonline, Tidak Gunakan UU Pers, Dakwaan JPU Tidak Diterima Hakim (Not using Law regarding Press, Prosecutor's Indictment has been Rejected by Judges), available at http://hukumonline. com/detail.asp?id=16468\&cl=Berita (last visited on January 03, 2014).

${ }^{62}$ Detik Online, Erwin Bebas, Jadi Kado Ultah Setahun Majalah Playboy (Edwin released become First Birthday's Present to Playboy Magazine), available at http://www.detiknews.com/index.php/detik. $\mathrm{read} / \mathrm{tahun} / 2007 / \mathrm{bulan} / 04 / \mathrm{tgl} / 05 /$ time/135019/idnews/763582/idkanal/10 (last visited on September 22, 2013). 
Equal support also came from liberal groups which throughout the due process supported Playboy Indonesia. As one respondent explained:

"AJI Indonesia warmly accepts the decision, which shows that truth and fairness finally prevail. This decision is an invaluable contribution to law enforcement concerning press independence against pressures from those who claim to act on behalf their groups' interests." ${ }^{\prime 3}$

Further, AJI Indonesia regarded the decision to have significantly contributed to the strengthening of the existence of Law No. 40/99 on the Press as a specific law regulating disputes related to news coverage and press publications in Indonesia. A similar opinion also came from another respondent, who expressed his satisfaction to judges' decision to Playboy case.

"Police and prosecutors must take lessons from this decision, that they must implement the Press Law to deal with legal cases concerning journalistic works." 64

However, the hardliners condemned the decision. The leader of FPI, for instance, argued that the Board of Judges made a grave mistake in acquitting Erwin Arnada from all legal charges. The leader of Hizbut Tahrir Indonesia (HTI), further added that, aside from being a bad precedent, the decision would also bring negative impacts upon the people.

"Setting Erwin free is a perfect precedent to legalize pornography in Indonesia. The gate to pornography has been breached open in Indonesia." 65

He also foresaw that future pornographic magazines will not only mushroom in Indonesia, but also be legal to do so. The police will be discouraged to take measures, but otherwise go against the people who fight against pornography. Therefore, according to this respondent, the Board of Judges had contributed to legalization of pornographic products in Indonesia.

\section{Freedom vs. Anarchy}

The era of political liberalism that begun in 1998, has transformed the whole political landscape in Indonesia. In the freedom of the press, for instance, mass media publications which were severely controlled and restricted, mushroomed under the new Press Law which eliminates the mandatory government's license for anyone who wishes to initiate a media business. According to data acquired from the Press Council, a steep increase in the amount of press companies occurred as early as one year after the fall of the New Order, from 289 to 829 companies. TV stations swelled from 6 stations to 65 , as well as radio stations from 740 to 1.100 stations. ${ }^{66}$ This data demonstrates an almost euphoric public participation to the forthcoming

\footnotetext{
${ }^{63}$ Hendratmoko, above $\mathrm{n} 22$.

${ }^{64}$ Atmakusumah, above n 45.

65 Interview with Muhammad Ismail Yusanto, Spokesperson, Hizbur Tahrir Indonesia. Hizbur Indonesia Tahrir (HIT) is an Islamic organization which fights for a kalifah style governmental system in Indonesia. Unlike FPI, HTI does not conduct acts of violence to pursue its purposes.

${ }^{66}$ Interview with Leo Batubara, Ex-Vice-Chairman of Press Council.
} 
era of liberalization. The newly acquired freedom, however, has undeniably brought negative excesses to Indonesian culture, for instance, the appearance of entertainment mass media with pornographic related content as their main feature.

The phenomenon of "pornographic" press at the outset was criticized and strongly opposed not only by the fundamentalist Islam, but also by their moderate counterparts as well as other religious circles in Indonesia. On this, for instance, one respondent of HTI Leader commented:

"We observe that the political freedom brought about by the reform movements has indeed been followed by cultural freedom; a freedom where mass media no longer takes into account the proper cultural norms and values. We of course regret and denounce this situation." 67

Another respondent of FPI Leader also is of a similar opinion:

"Freedom will no longer be attractive should there are no restrictions in it; therefore, a freedom is appealing when there are restrictions. There are no restrictions in Indonesia nowadays. We keep on talking about freedom, and that makes us inhuman. The problem lies where our social responsibility is." ${ }^{\prime \prime}$

In reality, the distribution of Playboy magazine seemed to be unregulated, as it could be found almost anywhere in Indonesia's major cities. This is what the hardliners refer to as unruly freedom. One respondent of HTI Leader stated that:

"In Japan, sale of Playboy magazines is regulated. In Singapore the magazine is even banned altogether, but here in Indonesia there are no regulations at all. In the United States where the magazine originated, sale of the magazine is also under strict rules e.g. must be displayed in a specific booth or shop window as to prevent children to buy it. But here in Indonesia, anybody sells them anywhere. This is way out of mind. Even liberals do not do this." ${ }^{9}$

On the distribution of Playboy magazine in Indonesia, the Press Council in their plenary session on 26 April 2006 decided that the first edition of the magazine issued in April was indeed not in observance to its segmentation mentioned in the magazine's front cover i.e. entertainment magazine for adult men, and therefore in breach of the Journalistic Code of Ethics in the context of protection to children and adolescences. ${ }^{70}$ In this decision, the Council also asserted that the magazine is a product of the press and thereby assessment to its content shall be based upon the Press Law. Nevertheless, the Press Council, prominent journalist figures, as well as people representatives realized the fact that there is no specific legal regulation concerning the distribution of mass media from adult entertainment genre.

One respondent, far before Playboy case became a controversy, has voiced the need to initiate a law on the distribution of adult entertainment

\footnotetext{
67 Yusanto, above n 65.

68 Rizieq, above n 46.

69 Yusanto, above n 65.

${ }^{70}$ Press Release, Dewan Pers, Dewan Pers number 07/P-DP/IV/2006 regarding Publishing of Playboy Indonesia Magazine (April 21, 2007).
} 
media in Indonesia.

"We propose to initiate a law on the distribution; hence any media that prompt controversy or protest from certain groups in the society must be distributed in limited places only. After such law is enacted, we must never allow any groups demand a prohibition against publication of certain media that does not conform to their ideology."71

Another respondent also added:

"We considered it wise to provide a complementary law on the distribution, particularly for media whose access must be restricted from underage. The Press Council has urged the parliament and other concerning parties to immediately draft this law."72

\section{Liberal Democracy vs. Anti-Democracy}

Constitutional amendment has given birth to a new political order in Indonesia that is more agreeable to liberal democratic principles. An inherent trait to the shift is the stepping aside of government from various important public and societal affairs to be taken over by civil society; which is apparent in the press industry. Under the new Press Law, the government very small part in press governance. There are no more government or ministerial regulations allowing interference with the industry; governance of the press is conducted in a self-regulatory manner. ${ }^{73}$ In order to promote the freedom of the press and national press based on the Press Law, an independent Press Council was established which functions, among others, to resolve press-related disputes and receive public complain on press coverage.

The Playboy magazine case is an interesting account as how the liberal democratic principles should be implemented amidst social political changes that seemingly happen to fast for the majority of the people to cope with, which in turn results in the emergence of anti-democratic movements based on various issues ranging from religious, ethnic, and quasi-nationalist in the "reformation era". The leader of FPI stated that:

"It is of great concern for all of us, that the government has power to control pornography but seems reluctant to do so. The government has the authority, apparatus, the law, and much more, but they simply refuse to do something about it." ${ }^{\prime \prime 4}$

Another respondent of HTI played similar tunes in this issue;

"The government should have reacted immediately, but they did nothing! We came to them, to the House of Representatives, to the Press Council, while bringing with us those pornographic magazines, demanding that they take immediate legal measures against the publisher; but they said they do not have the authority to do so."75

\footnotetext{
${ }^{71}$ Atmakusumah, above n 45.

72 Interview with Bambang Harimurti, Journalist, Ex-Member of the Press Council .

${ }^{73}$ Atmakusumah, above n 45.

${ }^{74}$ Rizieq, above n 46.

75 Yusanto, above n 65.
} 
The leader of Islamic Defenders Front praised Soeharto's measures to stop pornography.

"In Soeharto's era, despite all its shortcomings, prohibiting pornography and indecency did not require a law, did not require long-winded sessions in the House of Representatives. Soeharto just called a minister and said no kissing on TV. It was effectively done." ${ }^{\prime 76}$

Although liberals criticized Jakarta police measures in directly asking Playboy magazine to relinquish their circulation in the city due to security disturbances, this group in general congratulated President Susilo Bambang Yudhoyonos' (SBY) administration in leaving the case to legal institutions, despite Islamic groups' demands to the President to personally instruct the ceasing of Playboy magazine circulation throughout Indonesia. The Minister of Communication and Informatics of SBY administration, Sofyan Djalil, argues that the government, according to the Press law, has no authority to prohibit the magazine. ${ }^{77}$

One respondent also applauded SBY administration's neutrality toward press-related cases.

"SBY tried hard to be as neutral as possible toward human rights-related cases, particularly that concern with the freedom of expression and the freedom of the press. It is now up to legal institutions and civil society organizations to face those fundamentalists and conservatives." ${ }^{178}$

On the emergence of fundamentalist groups in this era of liberal democracy, another respondent opined that they are just small groups of people claiming to speak on behalf of the majority, trying to banish the hardfought freedom and liberty. "When Soeharto fell, we thought he was the only menace. Nonetheless, after his fall there emerged old elements which historically are threat to everyone's freedom." ${ }^{\prime 79}$ This respondent argues that these fundamentalist movements have ruined the harmony that has long been the foundation of the society. "They claim to save the people, but in reality they damage the unity of this nation" 80

One pro-democratic activist further added that the fundamentalist movement based on religion and ethnicity is the best possible threat to the liberal democracy that has since developed in Indonesia. "The future is up to pro-democracy individuals, can they consolidate themselves in face of those fundamentalists?"81 However, another respondent has a different opinion on the emergence of these fundamentalists. "I would rather point to the fact of social economic disparity as the cause of anti-democratic fundamentalists' emergence these days. If only our economic well-being for the majority is better than this, people will understand the principles of democracy, secularism, and such more easily; and eventually the radicalism will vanish by itself," ${ }^{\prime 2}$

\footnotetext{
${ }^{76}$ Rizieq, above n 46.

77 Tempo, above $\mathrm{n} 18$.

78 Atmakusumah, above n 45.

${ }^{79}$ Interview with Ahmad Taufik, Journalist, Tempo..

${ }^{80}$ Ibid.

${ }^{81}$ Interview with Robertus Robert, Pro-Democratic Activist.

$82 \quad$ Batubara, above n 66.
} 


\section{Case Analysis}

The controversy over Playboy, aside from its success in drawing massive public and even international attention, has provided an excellent opportunity in observing the rule of law in enforcing the freedom of the press in Indonesia. Violent actions conducted by Islamic hardliners including seizing and burning Playboy magazines in bookstores and news stalls, as well as damaging the magazine's representation office in Jakarta are evidence to the state's failure to protect fundamental freedoms of Playboy magazine owners and management which are legally and constitutionally guaranteed. Besides, Chief of Jakarta Police's appeal that Playboy magazine management for the time being stop their circulation in Jakarta due to security disturbance, also proves that the state, in this case the police, ignores its responsibility to guarantee the protection of the freedom of press.

From the field study's findings, it is apparent that fundamentalist Muslim movements in Indonesia, in expressing their views according to their comprehensive doctrine, do not adequately observe the public reason embodied in a democratic constitution which serves as a social contract between them and the rest of the people. They therefore failed to find a reasonable way to resolve disputes over the issue i.e. the publication of Playboy magazine. Fundamentalist Muslims clearly ignores public reason and try to force their understandings of the issue based on their own values and morality which they claim to be embodied in the Islamic Syari'ah.

This clearly does not conform to the philosophical basis elaborated by the founding fathers for this nation, where was implied that the state shall take a neutral stance toward all religions adhered by its citizens, and that it shall not incline towards any particular religion. Pancasila's attitude toward religion, as the state's fundamental norm, thus can be perceived as social contract among all elements of Indonesian peoples through their representatives in a proportional manner; a contract that still prevails since the independence, embodied in a democratic constitution.

Liberal democracy that guarantees freedom for every individual or group within society to express their views in social-political sphere was never meant to destabilize the society itself. More freedom for the Indonesian people was meant to consequently implement Pancasila, which acknowledges and looks forward to maintaining and even flourishing diversity and heterogeneity among the nation. This is then true even if some observers talk about the paradox of liberal democracy in Indonesia, that a hard-fought democracy, instead of preserving and flourishing diversity and heterogeneity among the nation, otherwise proves to be detrimental to the very objective it wishes to achieve, that has existed long before the birth of the nation itself, and has been democratically embodied and legitimized in a constitution since its independence.

Constitutional amendment that gave birth to a new political format and was conducted by democratically elected people's representatives assembled in the People's Consultative Assembly (MPR) as the implementer of people's sovereignty was a proof to the aspiration of the majority of this nation for a better democracy and rule of law in Indonesia. However, this better democracy 
and better freedom also gave way to the emergence of fundamentalist groups that based their claims to the aspirations and symbols of the religion of the majority; which posed a serious challenge to the future of the still-fragile liberal democracy in Indonesia.

The notion of public reason in Rawlsian paradigm is connected to essential elements of the constitution and the problem of basic justice i.e. fundamental rights and freedoms. Public reason is manifests in public political forum e.g. debates in case hearing before a court to determine what is just. Judges' decision in Playboy case is a good instance of how the constitution essentials concerning fundamental freedoms take shape in public reasoning within a public political forum. Notwithstanding the fact that hearing sessions in the Playboy case were always under considerable pressure particularly from Islamic hardliners, the judges of South Jakarta District Court found courage to decide the case purely and strictly based on prevailing laws. This decision is even more important in the context of human rights protection, in which a principle of the rule of law that requires judicial institution to take an impartial stance particularly when it comes to religious sentiment has been well implemented. In addition, the decision is democratically and constitutionally reasonable, and therefore publicly reasonable, since it has closely observed legal and constitutional principles.

Although the decision over Playboy case might be a milestone for liberal democracy in Indonesia and seemingly serves as a good example for Rawlsian paradigm of justice, the differences in historical and socio-cultural context between Indonesian people and Western societies undeniably are major factors that causes so many difficulties to consequently implement the rule of law and thus protect human rights in Indonesia up until recently. The Rawlsian paradigm takes for granted a condition of a well-established constitutional democracy where law and orders are all that matter; it is in this kind of situation public reason thus works.

Following the constitutional amendment, Indonesia has showed a strong commitment toward the rule of law and consequently a more liberal democracy, however it takes more time to attain what Rawls refer as a "well ordered society," where in maintaining justice and implementing the fundamental rights and freedoms the only mechanism that works is the public reason. A well-ordered society can only be achieved if dialectic and tensions among starkly differing comprehensive doctrines has found its convenient equilibrium, as a democracy progresses through its maturity. Realizing the fact that true democracy has just been initiated, Indonesia simply has yet to achieve such equilibrium.

It is clearly too early to talk about truly meaningful achievements in the development of liberal democracy in Indonesia, specifically in the fields of implementation of the rule of law and protection of human rights, since the liberal bearing has been set only after the fall of the New Order regime in 1998 and particularly after serial amendments to constitution during 1999 to 2002. This, combined with the fact that certain fundamentalist Muslim groups may be suspicious of westernization trends towards countries with Muslim majorities, consequently acts as fertile soil for the growth of anti-Western and particularly anti-American sentiment which may manifest in, among others, 
the proliferation of fundamentalist organizations in Indonesia; the Playboy case has given these organizations a perfect channel to vent their aspirations. On the other hand, taking lessons from this case, the sustainability of a more liberal democracy and well-implemented rule of law in Indonesia, as well as an actual protection to legally and constitutionally guaranteed fundamental rights and freedoms, for the time being seem to depend upon Indonesian legal institutions particularly the courts to serve as public political forum where the mechanism of public reason can hopefully works well, while all other circumstances are not yet conductive.

\section{Conclusion}

The Playboy magazine has been controversial due to; first, the inherent image of the magazine as an icon of international pornography. For fundamentalist Muslims, their rejection to the magazine is largely due to its image regardless of content, whereas for liberals, there is no justifiable reason for the rejection because the constitution and the law have guarantee protection to the freedom of the press. Second, there is an unsettling difference of values in perceiving the publication of Playboy magazine. For fundamentalist Muslims, publishing of the Playboy Magazine should notice Islamic ethics and moral values for Muslims that believed by majority of the Indonesian population. Therefore, it is supposed to be no place for Playboy Magazine in Indonesia; while for the liberals, as the magazine is not in violation to any existing laws, it then must be accepted as a consequence of liberal democracy. Third, seculars imply that behind their rejection to Playboy magazine due to pornography, lies a more fundamental, ideological, and historical rejection to liberalism, secularism, and capitalism; a claim that is confirmed by fundamentalist Muslims, that their struggle against liberalism, secularism, and capitalism is indeed an important part of Islamic law enforcement. Fourth, the absence of distribution of adult magazine regulation has been led to a free selling of Playboy magazine including for children's and teenagers buyers. Both liberals and fundamentalist Muslims are agree that this case is serious and the fact that there is a weakness of the legal institution.

The court's decision in the Playboy magazine case is very important to the sustainability of liberal democracy and the rule of law in Indonesia. However, it must not be perceived as a representation of how Indonesian courts provide protection to human rights for Indonesian people. Although constitutional amendment and legal reform have guaranteed the protection to human rights in general, its implementation largely depends on slow socio-cultural transformation of values and norms that have lived among Indonesian people for generations. The court decision in the Playboy case may represent a victory of liberal views that emphasizes on the freedom of expression and subsequently the freedom of the press over traditional culture that is excessively closed to sexuality. Although the magazine does not violate any laws, the majority of Indonesian people may find it difficult to accept that its presence is but a consequence of liberal democracy in Indonesia. For the time being, the Playboy case has proven that freedom, especially the freedom of the press, has a chance in Indonesia. 


\section{Bibliography}

Ahida, Ridha. (2005). Konsep Keadilan pada Masyarakat Multikultural Dilihat dari Perspektif John Rawls dan Will Kymlicka (Justice conception on Multicultural Society Seen from John Rawls and Will Kymlicka's Perspective). Doctoral Dissertation of Philosophy (Universitas Indonesia)

Ahmad, Khurshid. (1982). Islam: Its Meaning and Message. Kuala Lumpur: Dewan Pustaka Islam

An-Na'im, Abdullahi Ahmed. (2007). Islam dan Negara Sekular: Menegosiasikan Masa Depan Syari'ah (Islam and States: Negotiate The Future of Syari'ah). Jakarta: Mizan

Anshari, Endang Saifuddin. (1981) Piagam Jakarta 22 Juni 1945 (Jakarta Charter 22 Juni 1945). Bandung: Pustaka-Perpustakaan Salman ITB

Asshiddiqie, Jimly. (2005). Konstitusi dan Konstitusionalisme Indonesia (Constituion and Constitutionalism of Indonesia). Jakarta: Sekretariat Jenderal dan Kepaniteraan MKRI

Bagir, Zainal Abidin. (2006). Agama dalam Nalar Publik (Religion in Public Perspective). Paper on an Introduction to Discussion in Nurcholish Madjid Memorial Lecture, Yogyakarta 18 September 2006

Bedner, Andrian. (2007). Towards Meaningful Rule of Law Research: An Elementary Approach, paper on "Strengthening Social-Legal Studies" training in depok, 5-12 Juni 2007

Bowen, John R. (2003). Islam, Law and Equality in Indonesia: An Anthropology of public reasoning. Cambridge University Press

Denzin, Norman K. \& Yvonna S. Lincoln, ed. (1994). Handbook of Qualitative Research. SAGE Publication Inc.

Faiz, Pan Muhammad. (2005). Islam dan Persaingan Ideologi di Parlemen (Studi Kasus: Pro Kontra Pemasukan Tujuh Kata Piagam Jakarta ke Dalam Konstitusi pada Masa Reformasi (Islam and Ideological Competition in Parlement (Case Study: Pro-Contra of Included The Seven Words in Jakarta Charter to Constitution on Reformation Era). Jurnal Hukum Dan Pembangunan, No.2, April-Juni 2005

Fenwick, Stewart. (2007). Reading Rawls in Asia: Political Liberalism and Rule of Law in Indonesia. Paper on $4^{\text {th }}$ Annual ASLI Conference, Jakarta, May 2007

Garuda Nusantara, Abdul Hakim. (2003). Garuda Nusantara, HAM dalam Perspektif Hubungan Kelembagaan Nasional dan International Serta RAN (Human Rights on National and International's Perspective), paper on Seminar Pembangunan Hukum Nasional VIII, Bali 14-18 Juli 2003. Jakarta: Badan Pembinaan Hukum Nasional-Departemen Kehakiman dan HAM RI

Hefner, Robert W. (2000). Civil Islam: Muslims and Democratization in Indonesia Princeton: Princeton University Press, 2000

Huntington, Samuel P. (1997). The Clash of Civilization. Remarking of the World Order. New York: Simon \& Schuster

Kedourie, Elie. (1992). Politics in the Middle East. Oxford: Oxford University Press

Kusuma, Ananda B. (2006). Catatan Seputar Simposium Restorasi Pancasila, Prosiding Simposium Peringatan Hari Lahir Pancasila, Restorasi Pancasila: Mendamaikan Politik Identitas dan Modernitas (Pancasila: From Social Contract to State Ideology, Prosiding Symposium of Commemoration of Pancasila's Birth, Pancasila Restoration: Reconcile Identity and Modenity's Politic). Depok: Brighten Institute

Lewis, Bernard. (2002). What Went Wrong? Western Impact and Middle Eastern Response. Oxford: Oxford University Press 
Lindsey, Tim. (2004). "Indonesia: Devaluing Asian values, rewriting rule of law in Asian Discourses of Rule of Law" in Theories and implementation of rule of law in twelve Asian countries, France and the US. London and New York,: Routledge

Lindsey, Timothy. (1999). Indonesia: Law and Society. Sydney: The Federation Press

Lubis, Todung Mulya. (1999). The Rechtsstaat and Human Rights in Indonesia: Law and Society. Sydney: The Federation Press

Mahfud MD, Mohammad. (2006). Politik Hukum Menuju Pembangunan Sistem Hukum Nasional (Law Politics To Development Of National Legal System), paper on Seminar Arah Pembangunan Hukum Menurut UUD 1945 Hasil Amandemen di Jakarta, 29-31 Mei 2006

Majda El Muhtaj. (2005). Hak Asasi Manusia dalam Konstitusi Indonesia (Human Rights in Indonesia Constitution). Jakarta: Kencana

Mujani, Saiful. (2007). Muslim Demokrat: Islam, Budaya Demokrasi, dan Partisipasi Politik di Indonesia Pasca Orde Baru (Democratic Moslem: Islam, Democratic Culture, and Political Participation in Indonesia Post New Era). Jakarta: Gramedia Pustaka Utama

Nasution, Adnan Buyung. (2003). Implementasi Perlindungan Hak Asasi Manusia dan Supremasi Hukum (Implementation of Human Rights' Protection and Law Supremacy). Buku 2 Seminar Pembangunan Hukum Nasional VII, Jakarta: PNRI

Nusantara, Abdul Hakim Garuda. (2006). Arah Kebijakan Pembangunan Hukum Di Bidang Perlindungan, Pemajuan dan Penegakan Hak Asasi Manusia in Seminar Arah Pembangunan Hukum Menurut UUD 1945 Hasil Amandemen (Direction of Law Development On Field of Protection, Advancement and Enforcement of Human Rights in Seminar entitled "Direction of Law Development according to the Amandments of Indonesian Constitution 1945"). Jakarta: BPHN Deparemen Hukum dan HAM

Peerenboom, Randal ed. (2004). Asian Discourses of Rule of Law, Theories and implementation of Rule of Law in Twelve Asian Countries, France and the US. London and New York,: Routledge

Podhisita, Chai. (1991). Theoretical, Terminological and Philosophical Issue in Qualitative Research, in Bencha Yoddumnerm-Attig, et. Al., A Field Manual on Selected Qualitative Research Methods. Institutes for Population and Social Research Mahidol University

Rawls, John. (2001). A Theory of Justice. The Belknap Press

Rawls, John. (2002). The Law of People with 'the Idea of Public Reason Revisited. Harvard University Press

Ridhwan Indra Ahadian. (1991). Hak Asasi Manusia Dalam UUD 1945 (Human Rights in Indonesia Constitution 1945). Jakarta: Haji Masagung

Samuel Freeman ed. (1999). John Rawls: Collected Papers. Harvard University Press

Sumantri, Gumilar R. (2006). Pancasila Dalam Perubahan Sosial-Politik Indonesia Modern, Prosiding Simposium Peringatan Hari Lahir Pancasila, Restorasi Pancasila: Mendamaikan Politik Identitas dan Modernitas (Pancasila in Social Politic od Modern Indonesia, Prosiding Symposium of Commemoration of Pancasila's Birth, Pancasila Restoration: Reconcile Identity and Modenity's Politic). Depok: Brighten Institute

Todung Mulia Lubis. (2006). Pancasila, Globalisasi dan Hak Asasi Manusia, Prosiding Simposium Peringatan Hari Lahir Pancasila, Restorasi Pancasila: Mendamaikan Politik Identitas dan Modernitas (Pancasila, Globalization and Human Rights, Prosiding Symposium of Commemoration of Pancasila's Birth, Pancasila 
Restoration: Reconcile Identity and Modenity's Politic). Depok: Brighten Institute Wignjosoebroto, Soetandyo. (2002). Hukum: Paradigma, dan Dinamika Masalahnya (Law: The Paradigm and Dynamic of Its Problem). Jakarta: Lembaga Studi dan Advokasi Masyarakat

Wignjosoebroto, Soetandyo. (2003). Hubungan Negara dan Masyarakat dalam Konteks Hak Asasi Manusia: Sebuah Tinjauan Historik dari Perspektif Relativisme Budaya Politik, paper on Seminar Pembangunan Hukum Nasional VIII, Bali 14-18 July 2003. Jakarta: Badan Pembinaan Hukum Nasional-Departemen Kehakiman dan HAM RI

Yatim, Badri. (2001). Soekarno, Islam, Dan Nasionalisme (Islam and Nationalism). Bandung: Nuansa 